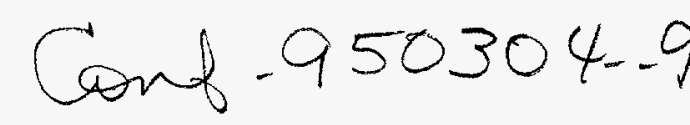

WSRC-MS-94-0367

\title{
HOT-WALL CORROSION TESTING OF SIMULATED HIGH LEVEL NUCLEAR WASTE (U)
}

by

G. T. Chandler, P. E. Zapp, and J. I. Mickalonis

Westinghouse Savannah River Company

Savannah River Site

Aiken, SC 29808

A paper proposed for presentation at the 1995 NACE International Annual Conference CORROSION/95

Orlando, Florida

March 26 - 31, 1995

and for publication in the proceedings

The information contained in this article was developed during the course of work under Contract No. DE-AC09-89SR18035 with the U. S. Department of Energy. By acceptance of this paper, the publisher and/or recipient acknowledges the U.S. Government's right to retain a nonexclusive, royalty-free license in and to any copyright covering this paper along with the right to reproduce, and to authorize others to reproduce all or part of the copyrighted paper.

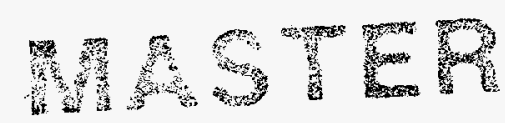




\section{DISCLAIMER}

This report was prepared as an account of work sponsored by an agency of the United States Government. Neither the United States Government nor any agency thereof, nor any of their employees, makes any warranty, express or implied, or assumes any legal liability or responsibility for the accuracy, completeness, or usefulness of any information, apparatus, product, or process disclosed, or represents that its use would not infringe privately owned rights. Reference herein to any specific commercial product, process, or service by trade name, trademark, manufacturer, or otherwise does not necessarily constitute or imply its endorsement, recommendation, or favoring by the United States Government or any agency thereof. The views and opinions of authors expressed herein do not necessarily state or reflect those of the United States Government or any agency thereof.

This report has been reproduced directly from the best available copy.

Available to DOE and DOE contractors from the Office of Scientific and Technical Information, P.O. Box 62, Oak Ridge, TN 37831; prices available from (615) 576-8401.

Available to the public from the National Technical Information Service, U.S. Department of Commerce, 5285 Port Royal Road, Springfield, VA 22161. 


\section{DISCLAIMER}

Portions of this document may be illegible in electronic image products. Images are produced from the best available original document. 


\title{
HOT-WALL CORROSION TESTING OF SIMULATED HIGH LEVEL NUCLEAR WASTE ${ }^{(1)}$
}

\author{
G. T. Chandler, P. E. Zapp, and J. I. Mickalonis \\ Westinghouse Savannah River Company \\ P.O. Box 616 \\ Aiken, SC 29808
}

\begin{abstract}
Three materials of construction for steam tubes used in the evaporation of high level radioactive waste were tested under heat flux conditions, referred to as hot-wall tests. The materials were type 304L stainless steel, alloy C276, and alloy G3. Non-radioactive acidic and alkaline salt solutions containing halides and mercury simulated different high level waste solutions stored or processed at the United States Department of Energy's Savannah River Site. Alloy C276 was also tested for localized corrosion susceptibility under steady-state conditions. The nickel-based alloys C276 and G3 exhibited excellent corrosion resistance under the conditions studied. Alloy C276 was not susceptible to localized corrosion and had a corrosion rate of $0.01 \mathrm{mpy}(0.25 \mu \mathrm{m} / \mathrm{y})$ when exposed to acidic waste sludge and precipitate slurry at a hot-wall temperature of $150^{\circ} \mathrm{C}$. Type $304 \mathrm{~L}$ was susceptible to localized corrosion under the same conditions. Alloy G3 had a corrosion rate of $0.1 \mathrm{mpy}(2.5 \mu \mathrm{m} / \mathrm{y})$ when exposed to caustic high level waste evaporator solution at a hot-wall temperature of $220^{\circ} \mathrm{C}$ compared to $1.1 \mathrm{mpy}(28.0 \mu \mathrm{m} / \mathrm{y})$ for type $304 \mathrm{~L}$. Under extreme caustic conditions (45 weight percent sodium hydroxide) $\mathrm{G} 3 \mathrm{had}$ a corrosion rate of $0.1 \mathrm{mpy}(2.5 \mu \mathrm{m} / \mathrm{y})$ at a hot-wall temperature of $180^{\circ} \mathrm{C}$ while type 304L had a high corrosion rate of $69.4 \mathrm{mpy}(1.8 \mathrm{~mm} / \mathrm{y})$.
\end{abstract}

Keywords: Alloy C276, alloy G3, type 304L stainless steel, cyclic potentiodynamic polarization, heat flux, high level radioactive nuclear waste

\section{INTRODUCTION}

Approximately 33.4 million gallons $\left(1.26 \times 10^{5} \mathrm{~m}^{3}\right)$ of highly radioactive waste solutions, from the production of nuclear materials at the United States Department of Energy's Savannah River Site, is presently stored in large

(1) The information in this article was developed during the course of work under Contract No. DE-ACO989SR18035 with the U. S. Department of Energy. 
underground carbon steel tanks (referred to as interim storage). The waste solutions contain approximately 35 to 40 weight percent (wt\%) dissolved solids in liquid supernate and about 5 to 10 volume percent (vol\%) insoluble solids or sludge. The dissolved solids are mainly sodium salts of nitrate, nitrite, hydroxide and aluminate. The insoluble solids are primarily precipitated oxides and hydroxides of iron, manganese, and aluminum. To minimize the waste volume for interim storage, the supernate is concentrated by evaporation and stored as mainly crystalline salt. Waste handling operations separate the waste into three parts: highly radioactive insoluble sludge, highly radioactive precipitate slurry, and decontaminated aqueous phase of dissolved salts. The highly radioactive sludge and precipitate slurry will be incorporated into a borosilicate glass matrix to immobilizg the radionuclides for permanent storage in a federal waste repository. The decontaminated salt solution will be immobilized by incorporation into a concrete waste form.

Evaporation of excess water is a frequently employed process step in radioactive waste management. Large volumes of water are required to dilute the non-radioactive species in the high level waste slurries, which are deleterious to vitrification processing and efficiency. Valuable waste tank space must be recovered by evaporation of aqueous waste solutions. In the vitrification process, the concentrations of radioactive species in the sludge and precipitate slurries are increased by evaporation before feed to the glass melter. These steps expose evaporator materials of construction to hot, aggressive conditions. In particular the tubing, through which high-pressure steam is introduced to heat the waste solutions, experiences high heat flux along with these conditions. This paper describes experiments on the effect of evaporator conditions on the corrosivity of various waste solutions on three evaporator steam tube materials.

\section{High Level Waste Evaporators}

Bent-tube high level waste evaporators are used to minimize the supernate waste volume for interim storage. Fresh waste can be reduced to approximately one third of its original volume. Upon concentration, the soluble solids exceed their respective solubility limits when the solution is cooled, and crystallize as saltcake. The solubility limit for sodium hydroxide is not achieved. As the solution becomes more concentrated, the sodium hydroxide concentration increases and consequently, the boiling point of the solution increases.

A schematic of a high level waste bent-tube evaporator is shown in Figure 1. The high level waste evaporators at the Savannah River Site are constructed of AISI type 304L stainless steel (304L). The steam tubes in the evaporators operate at approximately $180^{\circ} \mathrm{C}$ and process liquid temperatures range from $115-130^{\circ} \mathrm{C}$ with sodium hydroxide concentrations ranging from $15-35 \mathrm{wt} \%$.

Currently, a new evaporator is being designed to process larger volumes of waste and achieve greater volume reductions. The new evaporator is designed to operate at a steam temperature of approximately $220^{\circ} \mathrm{C}$ and liquid boiling temperatures of $130-180^{\circ} \mathrm{C}$ with sodium hydroxide concentrations ranging from $15-45$ wt \%. Because of the higher operating temperatures and higher hydroxide concentrations, $304 \mathrm{~L}$ is not an acceptable material of construction for the new evaporator. As shown in the isocorrosion chart in Figure 2, at the higher temperature range and higher hydroxide concentrations expected in the new evaporator, $304 \mathrm{~L}$ is susceptible to high general corrosion rates of greater than 30 mils penetration per year (mpy) and stress corrosion cracking.

Alloy G3, which is a nickel-base alloy, was chosen as the material of construction for the new high level waste evaporator. Nickel and nickel-base alloys are used extensively in high-hydroxide, high-temperature applications. ${ }^{2}$ The test program described in this paper was performed to determine corrosion rates for alloy G3 under heat flux conditions in caustic simulated high level waste to validate the material selection.

\section{High Level Waste Precipitate Slurry Evaporation}

Evaporation will also be used in processing high level waste sludge and precipitate slurries prior to vitrification into borosilicate glass. A simplified schematic of the evaporation process is shown in Figure 3 . Washed sludge is transferred to a process tank and then is $\mathrm{pH}$ adjusted with nitric acid. Nitric acid is used to obtain proper redox conditions for proper glass quality. The sludge is then evaporated to reduce the volume. The $\mathrm{pH}$ of the sludge ranges from 1-4. Steam tubes are operated at approximately $150^{\circ} \mathrm{C}$ and the process solution boils at approximately $100^{\circ} \mathrm{C}$.

Precipitate slurry from the hydrolysis reaction of cesium and potassium tetraphenylborate is then added to the sludge and boiled. Addition of the precipitate slurry increases the $\mathrm{pH}$ to approximately 9 . Mercury in the sludge reacts with formic acid and is reduced to its elemental state. Steam, generated by the boiling process, collect the mercury droplets and is removed from solution. The slurry is then mixed with glass frit and then melted and vitrified to form a 
The high level waste slurry process vessel is constructed of alloy C276, which is a nickel-base alloy. This alloy was selected based on corrosion studies performed by Bickford, et al. in $1984{ }^{3-5} 304 \mathrm{~L}$ was determined to be unacceptable for process solutions derived from sludge due to the combined effects of elevated temperatures and concentration of corrosive species, such as halides and mercury. Alloy $\mathrm{C} 276$ was found to perform exceptionally well under the expected conditions. However, a revised process scheme uses higher concentrations of nitric acid than previously tested. The current test program was performed to determine corrosion susceptibility of alloy C276 in processing high level waste precipitate slurries with more realistic nitrate concentrations. Corrosion rates were determined in liquid, vapor, liquid/vapor interface, condensate and heat flux conditions.

\section{EXPERIMENTAL PROCEDURE}

\section{Electrochemical Tests}

Cyclic potentiodynamic polarization (CPP) scans were performed to determine the susceptibility of alloy C276 to localized corrosion in simulated high level waste precipitate slurries. The ionic compositions of the test slurries are shown in Table 1. Solutions $\mathrm{A}, \mathrm{B}$, and $\mathrm{C}$ represent the high level waste slurry after $\mathrm{pH}$ adjustment using nitric acid. The slurry $\mathrm{pH}$ ranges from 2 to 6 , and the nitrate concentration ranges from 21,000 to $46,500 \mathrm{ppm}$. Upon heating to $95^{\circ} \mathrm{C}$ the solution $\mathrm{pH}$ decreases to approximately 1 . Solution $\mathrm{D}$ represents the slurry solution after adding the product from the precipitate hydrolysis reaction of cesium and potassium tetraphenylborate. The addition of the precipitate hydrolysis solution increases the $\mathrm{pH}$ of the slurry to approximately 9. The slurry solutions also simulate the $10-15$ wt $\%$ insoluble solids that are contained in radioactive sludge, such as hydroxides of iron, manganese, and aluminum. The CPP scans were run at room temperature and at $95^{\circ} \mathrm{C}$ in each slurry solution. The CPP technique was performed according to the ASTM Standard Test Method G 61-86.

\section{Coupon Immersion Tests}

Coupon immersion tests were also performed to determine general corrosion rates of alloy C276 coupons exposed to the liquid, vapor, liquid/vapor interface, and condensed vapor of simulated high level waste precipitate slurries. The exposure conditions were tested simultaneously in a 'Demo' flask, a diagram of which is shown in Figure 4. The tests were performed at $100^{\circ} \mathrm{C}$ for 14 days in simulated high level waste slurries similar in composition to Solution $\mathrm{C}$ and D in Table 1. ASTM Standard Practices G31-72 and G 1-90 were followed for these tests.

\section{Hot-Wall Tests}

Hot-wall corrosion tests were performed to determine corrosion rates for materials exposed to simulated high level waste under heat flux conditions. The tests were performed to simulate the experience of steam tubes in high level waste evaporators and in feed preparation systems for waste vitrification. The hot-wall test involves heating one side of a metal disc specimen while the other side of the specimen is exposed to a corrosive test solution.

A schematic of the hot-wall test set-up is shown in Figure 5. The test set-up uses a 3-liter Pyrex vessel with a 2-in. (5-cm)-inner-diameter side pipe to contain the test solution. Resistance heaters are used to heat a copper block in contact with one surface of a 1/8-in. (3-mm)-thick, 3-in. (7.6-cm)- diameter metal disc specimen. The other side of the disc specimen is in contact with the test solution through the vessel side pipe. Temperature on the hot-wall side is measured by a thermocouple through the heating block. Hot-wall temperature is controlled by a temperature feedbackloop controller. A reflux condenser maintains liquid level, and a cold finger condenser is used to maintain the bulk of the solution below the boiling point.

Alloy C276 samples were hot-wall tested in simulated high level waste slurry $\mathrm{pH}$ adjusted with nitric acid. The ionic composition of the test slurry is similar in composition to Solution $\mathrm{C}$ in Table 1 . The hot-wall temperature was maintained at $150^{\circ} \mathrm{C}$ for 28 days. Type $304 \mathrm{~L}$ samples were also hot-wall tested under these conditions for comparison.

Alloy G3 and 304L samples were hot-wall tested in simulated high level waste evaporator solutions at various degrees of concentration. Tests were performed in a relatively dilute feed solution, a moderately concentrated (typical) waste solution and a high concentration $45 \mathrm{wt} \%$ hydroxide solution. The compositions of the test evaporator solutions are shown in Table 2. The hot-wall temperature was maintained for 28 days at $220^{\circ} \mathrm{C}$ for the dilute and moderate 
concentration and $180^{\circ} \mathrm{C}$ for the 45 w\% hydroxide solution. Table 3 shows the test matrix for the hot-wall testing in slurry and evaporator solutions.

Specimens were prepared, cleaned, and evaluated using ASTM standard practice G 1-90. Deposits formed on the exposed surface of the samples were removed by mechanical scraping and thermal shocking in water. The deposits were analyzed by $\mathrm{x}$-ray diffraction (XRD) analysis and Scanning Electron Microscopy / Energy Dispersive Spectroscopy (SEM/EDS). Remaining deposits were removed by cleaning in acid solutions. Alloy C276 and alloy G3 samples were cleaned in 15 vol\% hydrochloric acid solution for several minutes. Type $304 \mathrm{~L}$ samples were cleaned in 10 vol\% nitric acid solution for several minutes.

\section{RESULTS AND DISCUSSION}

\section{High Level Waste Precipitate Slurries}

Electrochemical Tests. The cyclic potentiodynamic polarization (CPP) scans of alloy C276 in simulated high level waste precipitate slurry revealed immunity from localized corrosion (pitting). The scans with Solution A (Table 1) with a low $\mathrm{pH}$ of 2 showed standard passive and transpassive behavior, and the reverse scan current response was less than or equal to the forward scan response, indicating the immunity. The Solution $\mathrm{C}$ with the higher $\mathrm{pH}$ of 6 yielded similar results of immunity from pitting, with a somewhat smaller potential range showing passive behavior. In the Solution D test with a pH of 9 , the current response showed two active-passive transitions on the forward scan, but again a reverse scan current response well below the forward scan response, indicating pitting immunity.

Immersion Tests. Alloy C276 corrosion coupons in the 'Demo' flask showed no evidence of corrosion from boiling high level waste slurry after 14 days in $\mathrm{pH} 4$ slurry (Solution $\mathrm{C}$ in Table 1) and 14 days in $\mathrm{pH} 9$ slurry (Solution D). A fine brownish deposit was observed on all samples in the liquid, liquid/vapor interface, vapor, and condensate regions. This deposit is most likely composed of insoluble hydrated metal ions present in the sludge portion of the slurry. The deposit was easily removed by rinsing with water and revealed clean metal surface with no evidence of corrosion.

Hot-Wall Corrosion Tests. Alloy C276 hot-wall coupons showed little evidence of corrosion after 28 days of exposure in pH 4 slurry (Solution $\mathrm{C}$ in Table 1) at a hot-wall temperature of $150^{\circ} \mathrm{C}$ and a liquid boiling temperature of approximately $100^{\circ} \mathrm{C}$. As in the 'Demo' flask tests, a brownish deposit was observed on the exposed surface of the sample. Figure 6 shows the deposit on the alloy $\mathrm{C} 276$ disc sample after the hot-wall test.

The deposit was approximately $1 / 8^{n}$ thick and was adherent to the exposed surface. A significant amount of mechanical scraping was required to remove the deposit. $\mathrm{X}$-ray diffraction analysis of the deposit revealed that it was composed mainly of aluminum hydroxide and silicon oxide. Energy Dispersive Spectroscopy showed the presence of iron, manganese, and aluminum. As discussed before, the precipitate slurry contains approximately 15 wt $\%$ insoluble solids composed primarily of hydroxides of metal ions ( $\mathrm{Fe}, \mathrm{Mn}, \mathrm{Al})$ in the sludge portion of the slurry. The insoluble sludge coats the exposed metal surface and becomes adherent to the surface. After removal of the deposit, very little evidence of corrosion was observed. The corrosion rate was determined to be $0.01 \mathrm{mpy}(0.25 \mu \mathrm{m} / \mathrm{y})$.

The $304 \mathrm{~L}$ sample also had a thick sludge deposit on the exposed surface after hot-wall testing under the same conditions. The sludge deposit could not be completely removed, therefore, a corrosion rate could not be determined. Clean metal surface with little evidence of corrosion was observed under the portions of the deposit that could be removed. However, significant localized attack (pitting) was observed on the gasket area of the sample.

Previous coupon immersion tests were performed at the DuPont Engineering Test Center in the 1980's under expected process conditions. ${ }^{3-5}$ A revised process scheme and the current test program use higher concentrations of nitric acid than previously tested. The current nitrate ion concentration is approximately 50,000 parts per million (ppm) and the most comparable solution in the previous testing contained approximately $2000 \mathrm{ppm}$ nitrate with no sludge present. The previous tests revealed a corrosion rate of $3-4 \mathrm{mpy}(76-100 \mu \mathrm{m} / \mathrm{y})$ compared to $0.01 \mathrm{mpy}(0.25 \mu \mathrm{m} / \mathrm{y})$ in the current testing with alloy $\mathrm{C} 276$. The lower corrosion rate is most likely due to protection provided by the sludge deposit formed on the exposed surface. The sludge deposit may serve as a physical barrier to more aggressive species such as nitrate, chloride, and mercury. This is consistent with results obtained in a corrosion surveillance program performed in prototypic high level waste slurry processing equipment. ${ }^{10}$

Lacalized corrosion becomes a concern if the sludge deposit is not continuous or is not protective and results 
in à concentration cell effect. However, as discussed earlier, electrochemical testing has shown that alloy C276 is not susceptible to localized attack under these conditions. Type 304L, however, was found to be susceptible to localized corrosion under these conditions, which is consistent with the earlier testing. Based on past testing and current testing and surveillance programs, alloy C276 is expected to perform satisfactorily in the processing of acidic and basic high level nuclear waste precipitate slurries.

\section{Caustic High Level Waste Evaporator Solutions}

Hot-Wall Corrosion Tests. As in the case of hot-wall testing of precipitate slurries, a deposit formed on the exposed surfaces of the samples after exposure to the evaporator solutions. X-ray diffraction of the deposits revealed that they are composed mainly of sodium nitrate and hydrates of sodium aluminum nitrate and sodium carbonate. Similar deposits have been observed on carbon steel samples hot-wall tested in simulated waste tank solutions. ${ }^{11}$ Figure 7 shows the deposit on the alloy G3 sample after the hot-wall test in dilute waste.

The deposit formed from exposure to dilute waste solution ( $3.8 \%$ hydroxide, $17.3 \%$ nitrate) was approximately $1 / 8$ in. $(3 \mathrm{~mm})$ thick. The deposit formed from the moderately concentrated waste solution (14.5\% hydroxide, $12.8 \%$ nitrate) was significantly thinner due to less nitrate present in the test solution. As the waste solution is evaporated, most of the sodium hydroxide remains in solution while the nitrate reaches saturation and precipitates from solution. No deposits were observed on the caustic only tests.

The deposits were removed by mechanical scraping and thermal shocking in water. The results of the hot-wall tests of alloy G3 and 304L exposed to caustic simulated high level waste evaporator solutions are shown in Table 3. Alloy G3 exhibited excellent resistance to corrosion under the conditions tested. With exposure to dilute caustic waste solution and moderately concentrated caustic waste solution at a hot-wall temperature of $220^{\circ} \mathrm{C}$, very low corrosion rates of 0.01 and $0.1 \mathrm{mpy}(0.25$ and $2.5 \mu \mathrm{m} / \mathrm{y})$, respectively, were measured. With exposure to $45 \mathrm{wt} \%$ caustic only, which represents the highest expected level of hydroxide, alloy G3 showed excellent resistance at $0.1 \mathrm{mpy}(2.5 \mu \mathrm{m} / \mathrm{y})$ at a hot-wall temperature of $180^{\circ} \mathrm{C}$.

Type $304 \mathrm{~L}$ had higher hot-wall corrosion rates compared to alloy G3 in caustic evaporator solutions. 304L had good corrosion resistance when exposed to moderately concentrated caustic waste solution at a hot-wall temperature of $220^{\circ} \mathrm{C}$ with a corrosion rate of $1.1 \mathrm{mpy}(28 \mu \mathrm{m} / \mathrm{y})$. However, when exposed to high caustic solution at a hot-wall temperature of $180^{\circ} \mathrm{C}$, a high corrosion rate of $69.4 \mathrm{mpy}(1.76 \mathrm{~mm} / \mathrm{y})$ was measured. This is consistent with literature values for high-caustic high-temperature corrosion of $304 \mathrm{~L}$.

A new high level waste evaporator at the Savannah River Site is being designed to process larger volumes of waste and achieve greater volume reductions. The new evaporator will operate at a steam temperature of approximately $220^{\circ} \mathrm{C}$ and liquid boiling temperatures at $130-180^{\circ} \mathrm{C}$ with sodium hydroxide concentrations ranging from $15-45 \mathrm{wt} \%$. Based on the current hot-wall test program, alloy G3 is expected to perform significantly better than $304 \mathrm{~L}$ under these conditions.

\section{CONCLUSIONS}

The nickel-based alloys C276 and G3 exhibited excellent corrosion resistance in non-radioactive acidic and alkaline salt waste solutions under heat flux conditions. Type 304L stainless steel was susceptible to localized corrosion in acidic waste sludge and high corrosion rates in high caustic waste evaporator solutions under heat flux conditions. Based on the current test and surveillance programs and past test programs, alloy C276 and G3 are expected to perform satisfactorily in the processing of high level nuclear waste solutions.

\section{ACKNOWLEDGMENTS}

The authors wish to thank A. W. Lacey and A. L. Williams for their assistance in performing the corrosion tests.

\section{REFERENCES}

1. C. M. Schillmoller, Alloy Selection for Caustic Soda Service, (Houston, TX: Schillmoller Associates, 1988), p. 2.

2. Metals Handbook, 9th edition, Volume 13, Corrosion, (Metals Park, Ohio: ASM International, 1987), p. 1176. 
3. : R. A. Corbett, W.S. Morrison, and D.F. Bickford, Materials Performance, (1987).

4. M. K. Carlson, "DWPF Corrosion Report," OPS-WMQ-89-0059, June 26, 1989.

5. D. F. Bickford, R.A. Corbett, "Material Selection for Defense Waste Processing Facility," Joint ASM and International Nickel Co., International Conference on the Corrosion of Nickel Based Alloys Proceedings, Cincinnati, OH, (1984).

6. American Society for Testing and Materials Designations G 61-86, 1994 Annual Book of ASTM Standards, Vol. 3.02.

7. American Society for Testing and Materials Designations G 31-72, 1994 Annual Book of ASTM Standards, Vol. 3.02.

8. American Society for Testing and Materials Designations G 1-90, 1994 Annual Book of ASTM Standards, Vol. 3.02.

9. A. O. Fisher, F.L. Whitney, Jr., Corrosion-National Association of Corrosion Engineers, 15, (1959): p. 53.

10. K. J. Imrich, C. F. Jenkins, "Corrosion Study for a DOE Radioactive Waste Vitrification Facility," CORROSION/94, paper no. 115, (Houston, TX: NACE International, 1994).

11. J. C. Bovankovich, R. J. Cooper, and S. V. Fox, "Waste Sludge Hot-Wall Tests," DuPont Engineering Test Center Report Accession No. 16749, August 1983.

TABLE 1

COMPOSITION OF SIMULATED HIGH LEVEL WASTE SLURRIES

\begin{tabular}{lrrrr}
\hline & \multicolumn{4}{c}{ Concentration, ppm } \\
\cline { 2 - 5 } Species & Solution A & Solution B & Solution C & Solution D \\
\hline Fluoride & 7 & 28 & 133 & $<56$ \\
Formate & 4 & 1 & 1 & 48804 \\
Chloride & 1669 & 1851 & 1014 & 1612 \\
Nitrite & 95 & 335 & 10 & $<1$ \\
Nitrate & 36468 & 21294 & 46475 & 27614 \\
Sulfate & 33 & 203 & 167 & 736 \\
Oxalate & 16 & 18 & 13 & 103 \\
Phosphate & 1 & - & 1 & $<1$ \\
Insoluble solids & $\sim 15$ wt\% & $\sim 15$ wt\% & $\sim 15$ wt $\%$ & $\sim 15$ wt $\%$ \\
pH & 2 & 6 & 4 & $\sim 9$ \\
\hline
\end{tabular}


TABLE 2

COMPOSITION OF SIMULATED HIGH LEVEL WASTE EVAPORATOR SOLUTIONS

\begin{tabular}{llccc}
\hline & & & Concentration, wt\% \\
\cline { 3 - 5 } Component & $\begin{array}{c}\text { Dilute } \\
\text { Feed Solution }\end{array}$ & $\begin{array}{c}\text { Moderate } \\
\text { Concentration Solution }\end{array}$ & $\begin{array}{c}\text { High } \\
\text { Concentration Solution }\end{array}$ \\
\hline $\mathrm{NaOH}$ & sodium hydroxide & 3.8 & 14.5 & 45.0 \\
$\mathrm{NaNO}_{3}$ & sodium nitrate & 17.3 & 12.8 & - \\
$\mathrm{NaNO}_{2}$ & sodium nitrite & 3.1 & 11.0 & - \\
$\mathrm{NaAlO}_{2}$ & sodium aluminate & 2.2 & 7.6 & - \\
$\mathrm{Na}_{2} \mathrm{CO}_{3}$ & sodium carbonate & 0.5 & 1.6 & - \\
$\mathrm{Na}_{2} \mathrm{SO}_{4}$ & sodium sulfate & 0.6 & 0.4 & - \\
$\mathrm{NaF}$ & sodium fluoride & 0.03 & 0.01 & - \\
$\mathrm{NaCl}$ & sodium chloride & 0.04 & 0.17 & - \\
$\mathrm{Na}_{2} \mathrm{SiO}_{3}$ & sodium silicate & 0.05 & 0.05 & - \\
$\mathrm{Na}_{3} \mathrm{PO}_{4}$ & sodium phosphate & 0.04 & 0.10 & - \\
$\mathrm{Na}_{2} \mathrm{C}_{2} \mathrm{O}_{4}$ & sodium oxalate & 0.05 & 0.04 & - \\
$\left.\mathrm{Hg} \mathrm{NO}_{3}\right)_{2}$ & mercuric nitrate & 0.02 & 0.02 & - \\
\hline
\end{tabular}

TABLE 3

HOT-WALL CORROSION TESTS

\begin{tabular}{|c|c|c|c|c|c|c|}
\hline \multirow[b]{2}{*}{ Material } & \multirow[b]{2}{*}{ Solution } & \multirow{2}{*}{$\begin{array}{c}\text { Hot wall } \\
\text { Temperature }\end{array}$} & \multirow{2}{*}{$\begin{array}{c}\text { Liquid } \\
\text { Temperature }\end{array}$} & \multicolumn{2}{|c|}{$\begin{array}{c}\text { Corrosion } \\
\text { Rate }\end{array}$} & \multirow[b]{2}{*}{ Observations } \\
\hline & & & & mpy & $(\mu \mathrm{m} / \mathrm{y})$ & \\
\hline $\mathrm{C} 276$ & $\begin{array}{l}\text { precipitate slurry } \\
\text { pH adjusted with } \\
\text { nitric acid } \\
\text { (Solution C, TABLE 1) }\end{array}$ & $150^{\circ} \mathrm{C}$ & $100^{\circ} \mathrm{C}$ & 0.01 & $(0.25)$ & $\begin{array}{l}\text { - sludge deposit on surface } \\
\text { - clean surface under deposit } \\
\text { - no crevice corrosion }\end{array}$ \\
\hline 304L & $\begin{array}{l}\text { precipitate slurry } \\
\text { pH adjusted with } \\
\text { nitric acid } \\
\text { (Solution C, TABLE 1) }\end{array}$ & $150^{\circ} \mathrm{C}$ & $100^{\circ} \mathrm{C}$ & ND & (ND) & $\begin{array}{l}\text { - sludge deposit on surface } \\
\text { - significant crevice corrosion }\end{array}$ \\
\hline G3 & $\begin{array}{l}\text { evaporator feed solution } \\
\text { (TABLE 2) }\end{array}$ & $220^{\circ} \mathrm{C}$ & $106^{\circ} \mathrm{C}$ & 0.01 & $(0.25)$ & $\begin{array}{l}\text { - salt deposit on surface } \\
\text { - slight staining under deposit }\end{array}$ \\
\hline G3 & $\begin{array}{l}\text { concentrated evaporator } \\
\text { solution (TABLE 2) }\end{array}$ & $220^{\circ} \mathrm{C}$ & $118^{\circ} \mathrm{C}$ & 0.10 & $(2.5)$ & $\begin{array}{l}\text { - salt deposit on surface } \\
\text { - slight staining on surface }\end{array}$ \\
\hline G3 & $45 \mathrm{wt} \% \mathrm{NaOH}$ solution & $180^{\circ} \mathrm{C}$ & $135^{\circ} \mathrm{C}$ & 0.1 & $(2.5)$ & - no deposit on surface \\
\hline 304L & $\begin{array}{l}\text { concentrated evaporator } \\
\text { solution (TABLE 2) }\end{array}$ & $220^{\circ} \mathrm{C}$ & $118^{\circ} \mathrm{C}$ & 1.1 & $(28.0)$ & $\begin{array}{l}\text { - salt deposit on surface" } \\
\text { - staining on surface }\end{array}$ \\
\hline 304L & $45 w t \% \mathrm{NaOH}$ solution & $180^{\circ} \mathrm{C}$ & $135^{\circ} \mathrm{C}$ & 69.4( & $1.8 \mathrm{~mm} / \mathrm{y})$ & - no deposit on surface \\
\hline
\end{tabular}

ND not determined, unable to remove all of deposit

* sludge deposit composed mainly of aluminum hydroxide and hydrates of iron and manganese

** salt deposit composed mainly of sodium nitrate and hydrates of sodium aluminum nitrate and sodium carbonate 


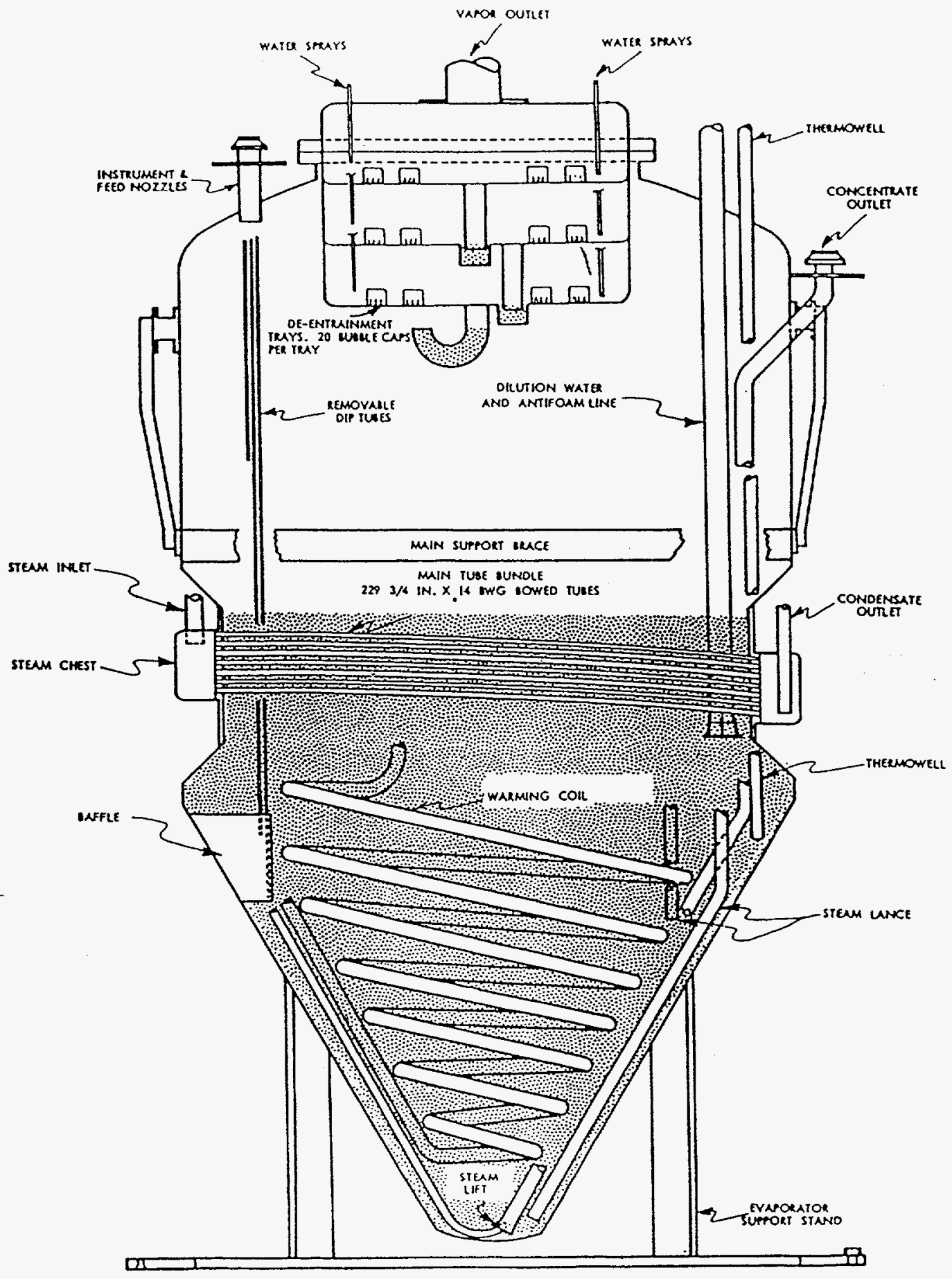

Figure 1 - Schematic of high level waste bent-tube evaporator 


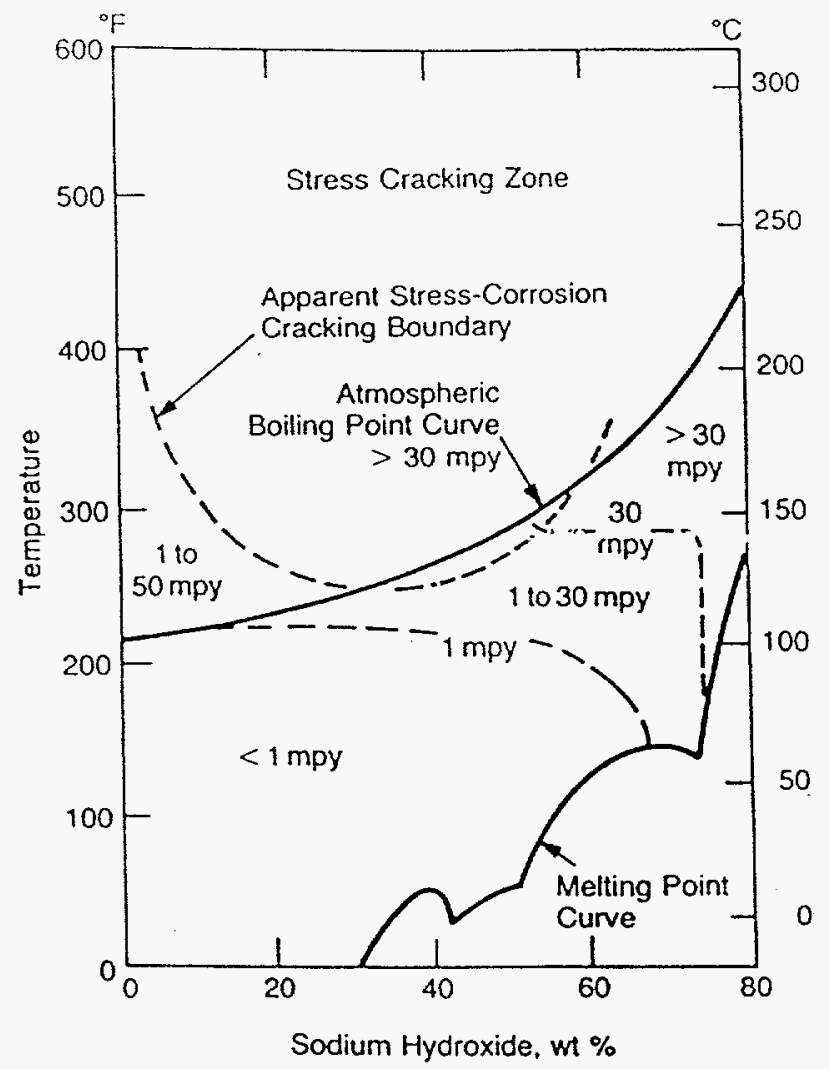

Figure 2 - Isocorrosion chart for AISI 304 and 316 stainless steels in sodium hydroxide, with stress cracking boundary superimposed (Reference 2)

High Level Precipitate Slurry After

Hydrolysis of Cesium and Potassium Tetraphenylborate

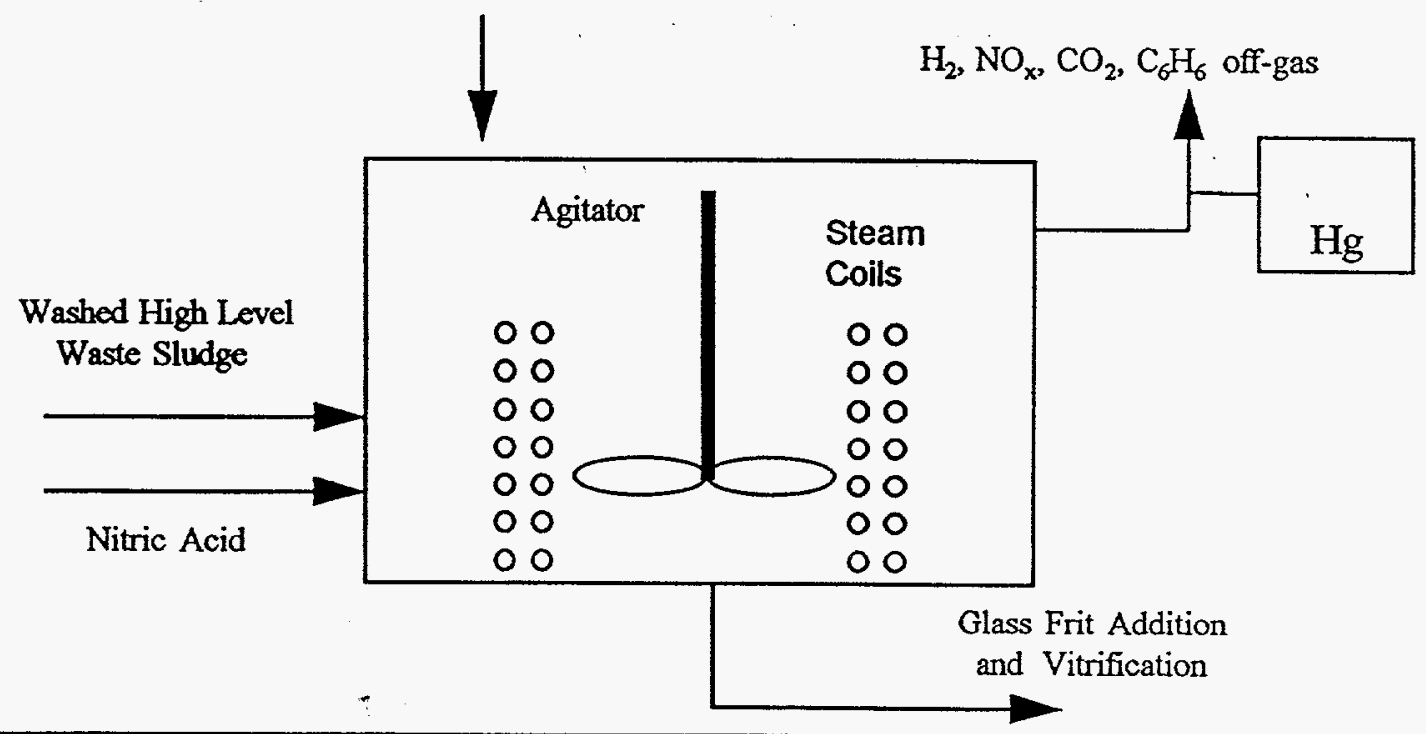

Figure 3 - Schematic of evaporation process for high level waste sludge and precipitate slurry 


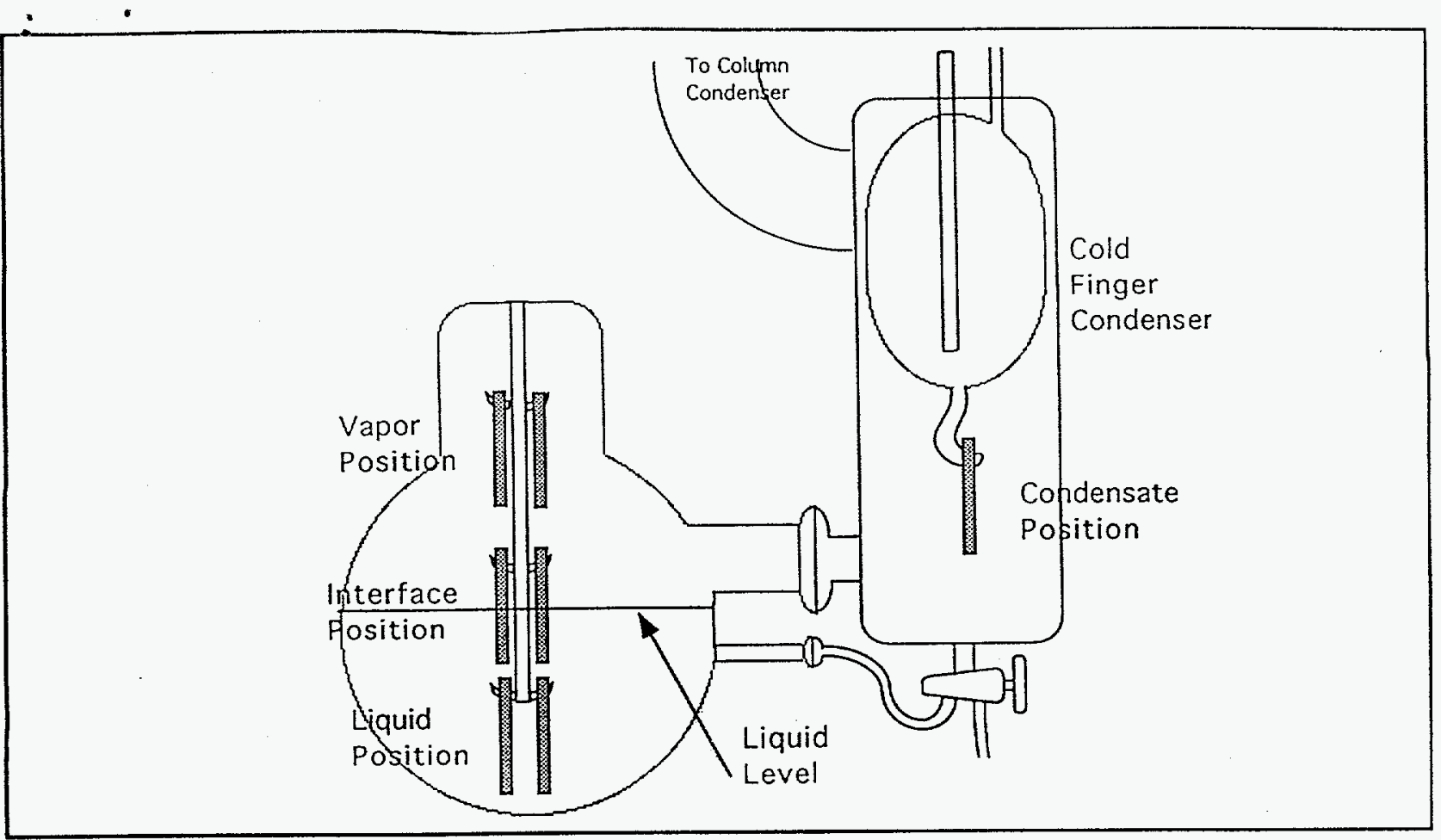

Figure 4 - Diagram of 'Demo' flask setup

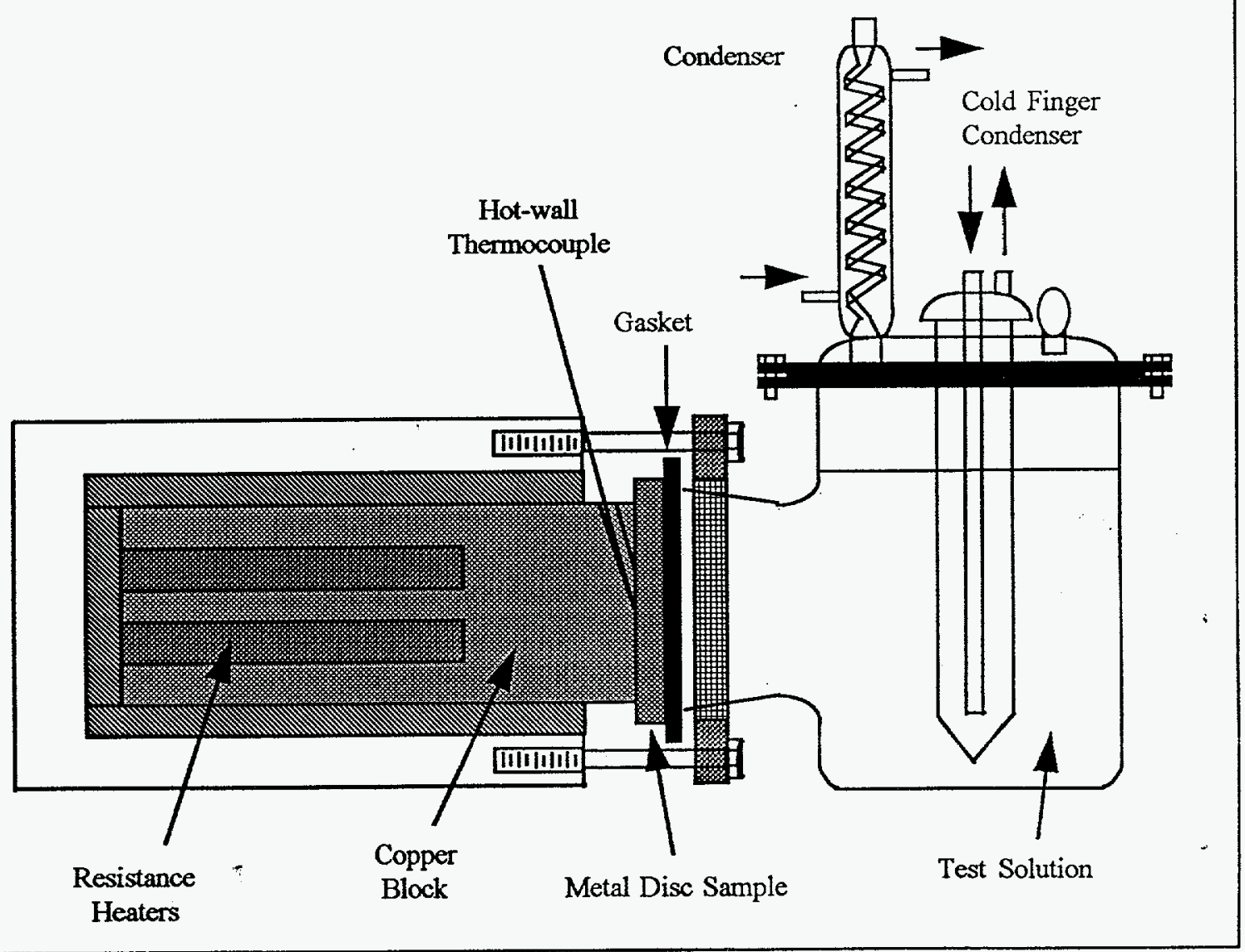

Figure 5 - Schematic of hot-wall setup 


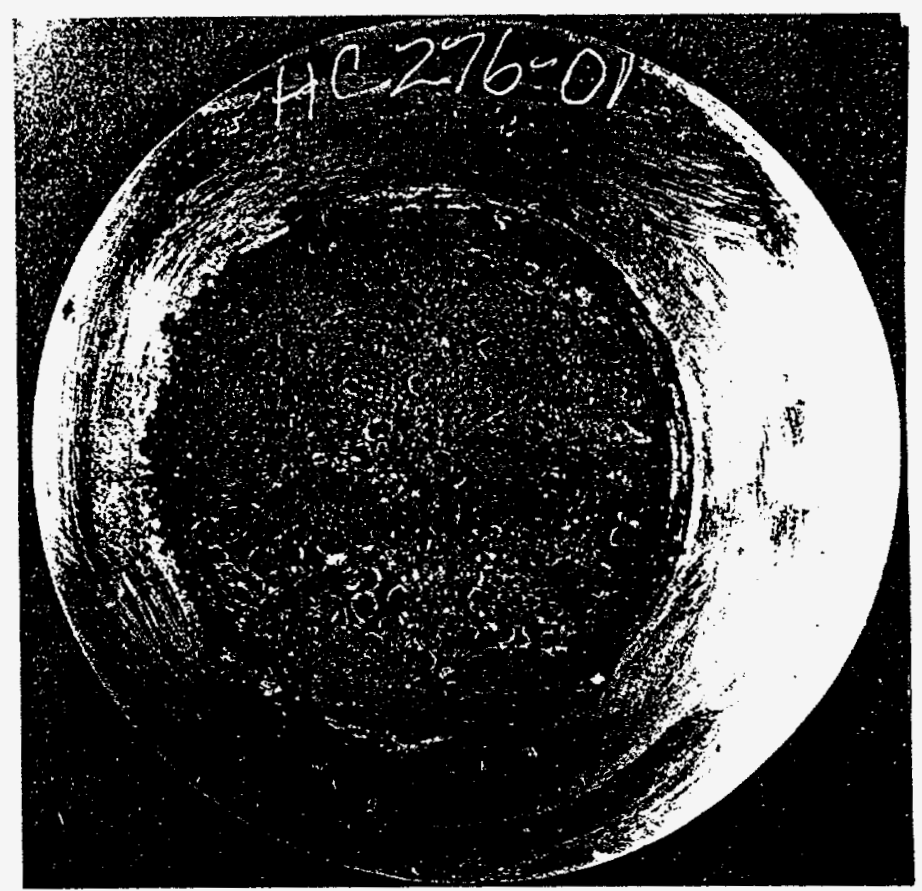

Figure 6 - Alloy $\mathrm{C} 276$ hot-wall disc sample after exposure to simulated high level waste sludge and precipitate slurry (28 day exposure, hot-wall temperature $=150^{\circ} \mathrm{C}$ )

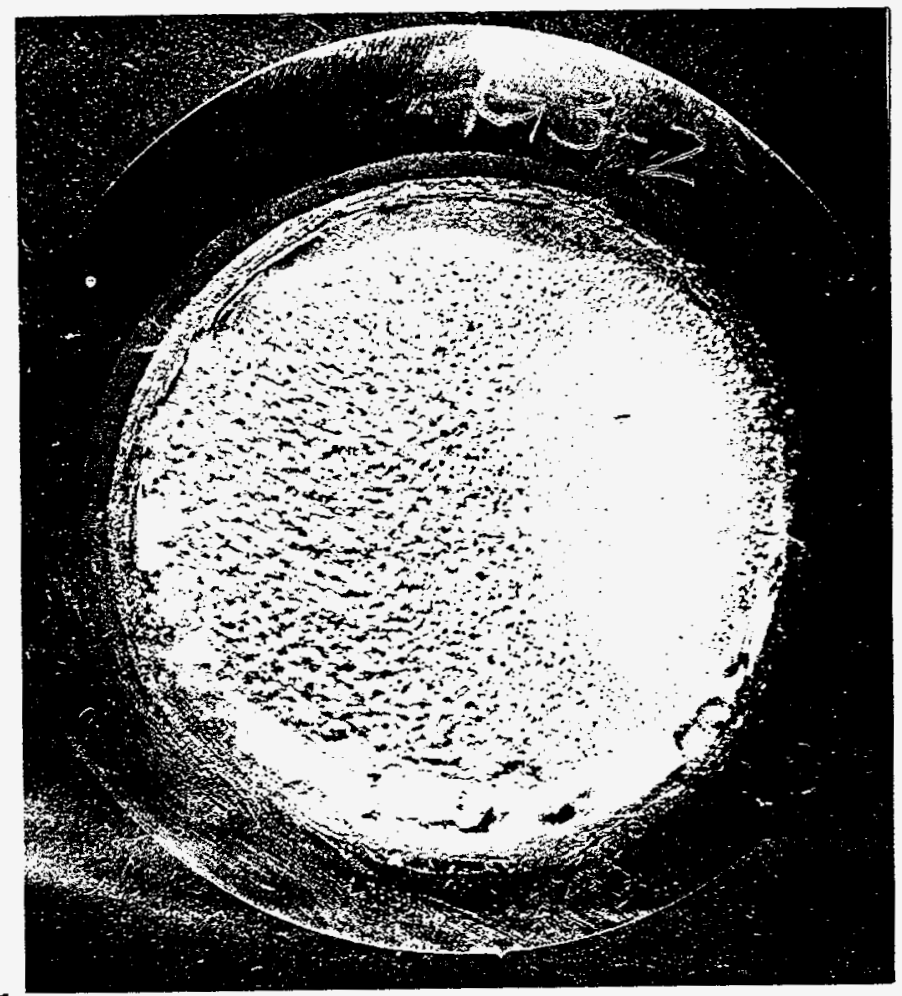

Figure 7 - Alloy G3 hot-wall disc sample after exposure to simulated high level waste evaporator solution ( 28 day exposure, hot-wall temperature $=220^{\circ} \mathrm{C}$ ) 